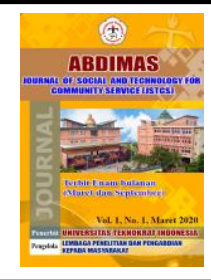

\title{
PENGGUNAAN KOMIK DIGITAL TOONDOO DALAM PEMBELAJARAN BAHASA INGGRIS TINGKAT SEKOLAH MENENGAH
}

\author{
Achmad Yudi Wahyudin ${ }^{1}$, Jepri Daud ${ }^{2}$, Martha Widiawitasari Simamora ${ }^{3}$, Irma Widya \\ Pratiwi $^{4}$, Alfa Rina ${ }^{5}$ \\ Universitas Teknokrat Indonesia ${ }^{1,2,3,4,5}$ \\ Email : achmad.yudi@teknokrat.ac.id
}

\begin{tabular}{lll}
\hline Received: January 10, 2020 & Accepted: February 10, 2020 & Published : March 15, 2020
\end{tabular}

\begin{abstract}
The present study investigate the use of comic strip creator Toondoo in the teaching of recount text in the secondary education. With the participation of one English teacher, the study tried to capture the process of creating comic as a media of teaching in an academic year of 2018-2019 in a public school in Lampung, Indonesia. Observation was used as the data collecting technique. The results shows the process of comic creator with the element of recount text. The process of comic writing consists of registration, creating layout, selecting comic character, selecting background, creating balloon, and publishing comic. These process was integrated into the teaching and learning process in the classroom. This study may give pedagogical implication for teachers and practitioners in secondary education.
\end{abstract}

Keywords: comic strip, Toondoo, motivation, recount, secondary students

\begin{abstract}
Abstrak
Studi ini menyelidiki penggunaan Toondoo pembuat komik strip dalam pengajaran teks recount di pendidikan menengah. Dengan partisipasi seorang guru bahasa Inggris, penelitian ini mencoba menangkap proses pembuatan komik sebagai media pengajaran pada tahun akademik 2018-2019 di sekolah umum di Lampung, Indonesia. Observasi digunakan sebagai teknik pengumpulan data. Hasilnya menunjukkan proses pembuatan komik dengan elemen teks recount. Proses penulisan komik terdiri dari pendaftaran, membuat tata letak, memilih karakter komik, memilih latar belakang, membuat balon, dan menerbitkan komik. Proses ini diintegrasikan ke dalam proses belajar mengajar di kelas. Studi ini dapat memberikan implikasi pedagogis bagi guru dan praktisi dalam pendidikan menengah yang dapat dibantu dengan penggunaan komik.
\end{abstract}

Kata Kunci: komik strip, Toondoo, motivasi, recount, sekolah menengah

\section{INTRODUCTION}

Mengajar Bahasa Inggris sebagai bahasa asing di Indonesia telah diamanatkan dalam kurikulum nasional sejak 1954 (Emilia, 2005 dikutip dalam Wahyudin, 2015). Saat ini, Kurikulum 2013 mengamanatkan bahwa proses pembelajaran standar untuk mata pelajaran Bahasa Inggris harus dapat membangun keterampilan siswa dalam mendengarkan, berbicara, membaca dan menulis. Mengacu pada kurikulum 2013, tujuan pengajaran bahasa Inggris di sekolah menengah pertama adalah bahwa siswa harus dapat mengembangkan kompetensi komunikatif secara tertulis atau dalam bentuk lisan untuk mencapai tingkat literasi fungsional. Pada abad ke-21, juga dikenal sebagai era revolusi industri, 4.0 siswa harus dibangun lebih awal untuk tidak hanya menguasai literasi bahasa asing tetapi juga literasi digital. Mereka diharapkan dapat berkomunikasi baik dalam bentuk lisan maupun tulisan baik di dalam maupun di luar jaringan untuk menyelesaikan masalah dalam kehidupan seharihari.

Pada dasarnya, menulis adalah keterampilan bahasa yang paling rumit untuk dikuasai. Ini wajar karena menulis melibatkan banyak aspek, yaitu konten, organisasi, kosa kata, penggunaan bahasa, dan mekanisme penulisan. Konten adalah aspek penulisan yang mengacu pada kesatuan paragraf, organisasi mengacu pada 
koherensi, perjanjian kosakata dengan pemilihan kata, penggunaan bahasa yang fokus pada tata bahasa, dan mekanika merujuk pada tanda baca dan penggunaan huruf besar dan kecil.

Namun, tujuan pembelajaran ini sangat sulit dicapai jika Anda melihat keterampilan menulis siswa yang jauh dari target pembelajaran mereka. Sejalan dengan penelitian yang dilakukan oleh Wahyudin (2012) menemukan bahwa sebagian besar siswa tidak dapat mengekspresikan ide-ide mereka secara tertulis karena mereka tidak memiliki kosa kata bahasa Inggris yang memadai. Selain itu, Juwitasari (2005) menemukan bahwa banyak siswa tidak dapat mengekspresikan ide-ide mereka dengan baik dalam esai karena kurangnya pemahaman tentang struktur generik dan karakteristik linguistik dari teks bahasa Inggris.

Berdasarkan pengalaman mengajar melamar di tingkat SMP, dapat dilihat bahwa siswa memiliki masalah dalam mengembangkan ide untuk menulis ke dalam bahasa Inggris. Ketika guru mereka meminta untuk membuat esai, mereka tampak bingung untuk mengekspresikan ide-ide mereka dalam bentuk tertulis. Ini mungkin karena beberapa alasan: pertama, siswa tidak tahu teknik spesifik yang dapat membimbing mereka dalam mengembangkan ide-ide mereka (Wahyudin, 2012). Kedua, mereka hampir tidak pernah mendapatkan pelatihan menulis (Juwitasari 2005), dan ketiga, banyak guru bahasa Inggris masih mengajar menulis dengan cara dan teknik konvensional dalam pengajaran teks. Sutarsyah (2017) menunjukkan bahwa saat ini, sebagian besar guru bahasa Inggris hanya melaksanakan pengajaran mereka menggunakan metode tradisional. Beberapa guru Bahasa Inggris hanya memberi siswa beberapa topik untuk ditulis tanpa memberikan pedoman bagi siswa dalam menulis paragraf. Akibatnya, siswa selalu bingung ketika diminta untuk menulis dan mereka berpikir bahwa menulis itu membosankan dan sulit untuk dipelajari.

Faktor utama yang menyebabkan kurangnya keterampilan dan minat menulis adalah penggunaan media pengajaran yang kurang efektif. Oleh karena itu, siswa memerlukan penggunaan media sesuai dengan waktu untuk merangsang dan mengaktifkan ide-ide mereka untuk menghasilkan tulisan lebih mudah. Dengan demikian, penggunaan media yang efektif diharapkan dapat menciptakan kelas menulis yang lebih menarik. Media juga dapat digunakan oleh guru bahasa Inggris untuk mentransfer materi pembelajaran untuk mencapai tujuan pembelajaran dan meningkatkan keterampilan menulis siswa. Belajar menulis sangat tergantung pada efektivitas teknik dan penggunaan guru media bahasa Inggris. Sangat penting bagi guru Bahasa Inggris untuk membuat semacam terobosan dalam mengajar, dengan mencoba menggunakan media yang sesuai dengan zaman untuk menarik siswa dan mendukung pembelajaran menulis.

Salah satu media yang menarik pembelajar di tingkat menengah adalah komik. Komik merupakan media yang sangat populer bagi kalangan pembelajar di usia 11-15 tahun karena media tersebut menampilkan cerita yang disertai dengan gambar yang menarik. Gambar pada komik dapat berupa karakter berbentuk kartun manusia, hewan, tumbuh-tumbuhan dan sebagainya. Komik juga dilengkapi dengan balon berisikan cerita dan percakapan yang membuat masyrakat lebih tertarik membaca. Dalam perkembangan teknologi dan informasi komik dapat dibuat dengan mengakses laman penyedia pembuatan komik, salah satunya bernama Toondoo. Toondoo yang dapat diakses pada www.toondoo.com merupakan web pembuat komik daring. Toondoo dilengkapi fitur pembuatan akun, pemilihan warna, karakter, dan penulisan teks yang dapat disematkan pada kolom gambar komik maya. Toondoo saat ini diminati para pengguna karena kemudahan dalam mengakses dan tampilan yang ramah pengguna.

Dengan adanya laman pembuat komik Toondoo, penulis mencoba melihat penggunaan Toondoo dalam pembelajaran Bahasa Inggris. Pembelajaran Bahasa Inggris pada tingkat menengah disusun berdasarkan genre. Salah satu genre yang diajarkan pada pembelajaran tingkat menengah adalah teks recount. Teks recount dipilih karena memiliki fitur bahasa Inggris yang unik, menggunakan tenses past dan past continuous serta penggunaan sudut pandang orang pertama tunggal. Teks recount memiliki struktur orientation, event, dan re-orientation. Dalam teks ini penulis bertujuan untuk menceritakan kembali kejadian lampau. Dalam kaitannya dengan Toondoo penulis akan menerapkan proses pengajaran teks recount dengan mengkombinasikan Toondoo sehingga, pembelajar atau siswa nantinya dapat mempelajari teks recount dengan menggunakan Toondoo. Teks recount yang dihasilkan dapat berbentuk komik. Studi dalam karya tulis ini berupa kegiatan pengabdian kepada masyarakat (PKM) yang didanai oleh Kemntrian Riset dan Teknologi Republik Indonesia dalam skema Program Kemitraan Masyarakat Stimulus (PKMS).

\section{METODE PELAKSANAAN}

PKMS merupakan program Kemntrian Riset dan Teknologi Republik Indonesia untuk menstimulasi perguruan tinggi untuk dapat meningkatkan kinerja pengabdian kepada masyarakat di perguruan tingginya. Khalayak sasaran program PKMS dapat mencakup: 1) masyarakat yang produktif secara ekonomi; 2) masyarakat yang belum produktif secara ekonomis, tetapi berhasrat kuat menjadi wirausahawan; atau 3) masyarakat yang tidak produktif secara ekonomi (masyarakat umum/biasa). 
Journal of Social and Technology for Community Service (JSTCS), Vol: 01, No: 01, 1-6

Pada program PKMS ini, sasarannya adalah guru dan siswa di SMP Negeri 2 Sekampung Udik Timur Lampung di mana 32 siswa Kelas 8 ikut serta dalam kegiatan ini. Kelas 8 dipilih secara purposive sebagai peserta kegiatan karena mereka sudah memiliki keterampilan bahasa Inggris dasar yang memadai. Selain itu isi kegiatan PKMS sesuai dengan program pembelajaran dan kurikulum di tingkat itu. Program ini diharapkan dapat menyelesaikan masalah di mana nilai rata-rata mata pelajaran bahasa Inggris di siswa SMPN 2 Sekampung cukup rendah. Secara detail implementasi kegiatan PKMS dapat dilihat pada grafik berikut. Kegiatan PKMS dilakukan melalui 3 tahap, yaitu: (1) Kegiatan; (2) kegiatan; dan (3) pasca kegiatan.

\section{HASIL DAN PEMBAHASAN}

\section{Pelaksanaan Program Kemitraan Masyarakat Stimulus (PKMS) pada SMPN 2 Sekampung Udik}

Pada bagian ini penulis akan menjelaskan secara rinci penggunaan Toondoo.com untuk menghasilkan komik digital yang cukup mudah diakses oleh guru dan siswa. Toondoo adalah alat pembuat komik berbasis web dan merupakan media pembelajaran untuk anak-anak. Toondoo diciptakan oleh perusahaan Jambav yang didedikasikan untuk membuat game edukasi untuk anak-anak. Proses pelaksanaan PKMS dapat dijabarkan sebagai berikut.

\section{Pra Kegiatan}

Kegiatan ini dimulai dengan analisis situasi yang terdiri dari analisis lokasi dan analisis masalah. Analsis lokasi merupakan proses penentuan lokasi kegiatan berdasarkan jarak tempuh, kemudahan untuk dijangkau, dan berada pada daerah di luar pusat kota. Analisis masalah merupakan proses penentuan peserta kegiatan berdasarkan masalah yang dihadapi dan kesesuaian bidang ilmu penulis. Penulis saat ini merupakan sivitas akademika salah satu kampus di Bandar Lampung yang memiliki tugas untuk melaksanakan pendidikan, penelitian, dan pengabdian pada masyarakat di bidang Pembelajaran Bahsa Inggris. Setelah itu dilanjutkan dengan persiapan pembuatan media pengajaran berbasis website yang menghasilkan komik digital. Instrumen yang digunakan dalam kegiatan ini adalah observasi, tes keterampilan menulis yang dirancang selama 90 menit dengan pilihan topik tentang pengalaman. Selain itu, kuesioner untuk mengukur tingkat minat siswa dalam belajar dengan komik juga disiapkan menggunakan skala likert 1 sampai 5. Setelah instrumen siap, penulis akan melakukan praobservasi ke lokasi SMPN 2 Sekampung Udik memperkenalkan secara detail rencana kegiatan PKMS dan melihat kondisi dan memahami karakteristik pembelajaran di sekolah. Pengujian instrumen seperti kuesioner juga dilakukan sehingga kuesioner yang didistribusikan selama pelaksanaan kegiatan cukup akurat untuk mengukur tingkat minat dan sikap siswa terhadap pembelajaran menulis teks recount menggunakan Toondoo. Dalam artikel ini penulis hanya akan fokus menjabarkan hasil observasi.

\section{Kegiatan Inti}

Kegiatan ini dimulai dengan proses tes awal, yaitu tes keterampilan menulis selama 90 menit atau dua jam belajar. Dalam proses ini siswa akan diuji kemampuan mereka dalam menulis teks recount tentang pengalaman pribadi mereka. Panjang esai tidak terbatas tetapi harus memenuhi unsur-unsur struktur penghitungan teks generik. Setelah tes pendahuluan dilakukan, penulis akan mulai mengajar pertemuan berikutnya. Penulis akan bertindak sebagai guru dengan menerapkan pembelajaran yang memenuhi aturan pembelajaran berbasis genre dengan menggabungkan penggunaan media komik digital kepada siswa melalui situs web Toondoo.com. Siswa juga akan diberikan tugas pengayaan dan pendalaman sehingga mereka juga dapat belajar secara mandiri di luar kelas. Kegiatan pembelajaran ini akan berlangsung selama enam pertemuan dan akan direkam menggunakan kamera digital. Pada saat yang sama, tim penulis juga akan membantu mereka untuk membantu menyelesaikan masalah teknis di lokasi kegiatan. Para guru juga diminta untuk dapat mengamati penggunaan komik strip digital ini sehingga mereka dapat menggunakannya nanti. Setelah pembelajaran selesai, siswa akan diminta mengisi kuesioner minat dan sikap terhadap pembelajaran menulis teks recount yang telah mereka peroleh. Berkaitan dengan hasil observasi penggunaan Toondoo ditemukan bahwa penggunaan Toondoo pada pengajaran Bahasa Inggris diterapkan sebagai berikut:

\section{A. Pendaftaran}

Pada tahap ini pengguna (baik guru dan siswa) dapat segera mendaftar secara gratis dengan mengklik pada pendaftaran secara gratis sehingga halaman pendaftaran akan muncul menanyakan nama pengguna, kata sandi, dan email pengguna. Setelah menyelesaikan pendaftaran, pengguna dapat langsung mengakses Toondoo dengan masuk sesuai dengan nama pengguna dan kata sandi yang terdaftar 


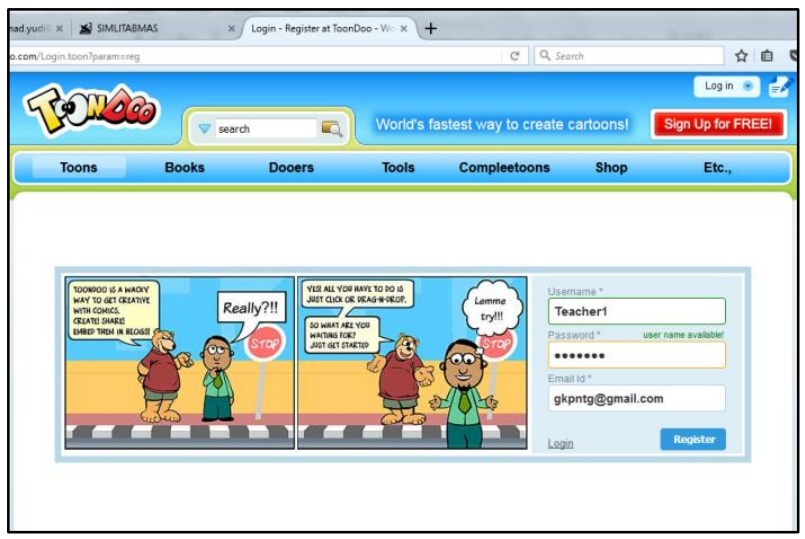

Gambar1. Pendaftaran

B Mengatur tata letak

Di halaman Toondoo.com, pengguna dapat memilih menu Toon dan memilih submenu Buat Toon. Setelah itu akan muncul halaman untuk memilih tata letak komik kita seperti gambar di bawah ini. Pengguna dapat mencoba menggunakan tata letak $2 \times 2$ untuk mencoba membuat komik untuk pertama kalinya.
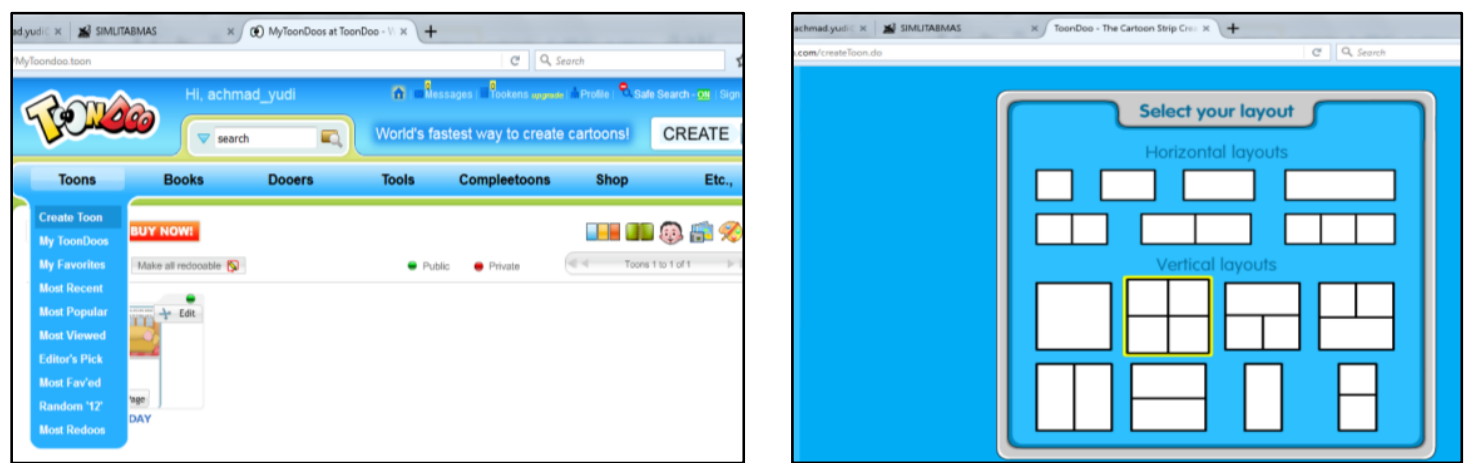

Gambar 2. Layout Options

C. Pembuatan karakter komik

Setelah memasuki halaman desain komik, siswa dapat memilih berbagai karakter seperti orang dewasa (pria atau wanita), anak-anak (pria atau wanita), hewan, karakter olahraga, emotikon, dan sebagainya. Untuk memasukkannya ke dalam komik, cukup geser karakter yang dipilih ke kolom komik. Pada gambar 4 terlihat hasil salah satu siswa membuat komik dengan karater kartun perempuan dengan latar belakang di dalam rumah dan ruang tamu. Pada gambar tersebut dapat terlihat komik yang mencakup karakter yang menarik dan tulisan yang terlihat jelas. Pada tulisan tersebut terdapat bagian dari teks recount berupa orientation yang bertuliskan On Saturday, I had a phone call from Ruby and she asked me to come by her house to celebrate his birthday party. Kalimat ini merupakan bagian orientation karena memperkenalkan konteks, situasi, di mana kejadian terjadi. 

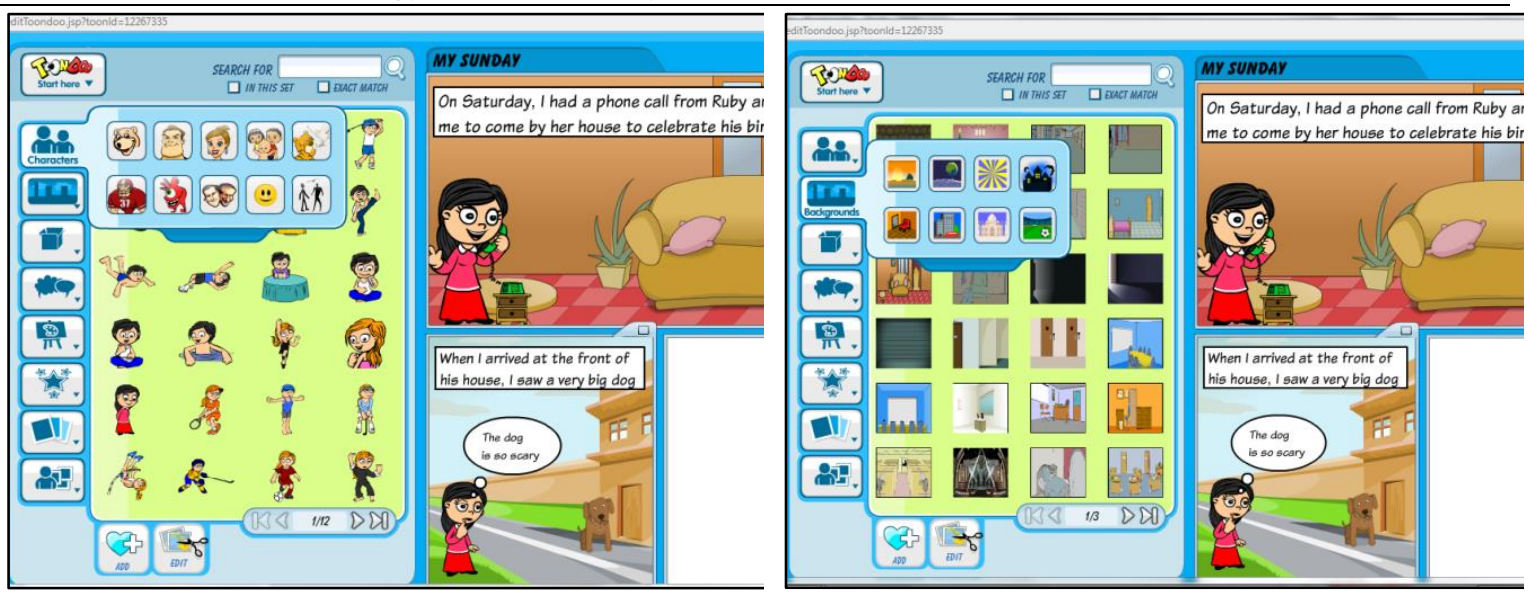

Gambar 4. Pemilihan Karakter dan Pemilihan Latar Belakang

D. Memilih gambar latar belakang yang tepat

Pada tahap ini, siswa menambahkan berbagai latar belakang komik seperti tempat dalam dan luar ruangan, lanskap, kota, malam atau siang hari. Untuk memasukkannya ke dalam komik, cukup geser latar yang dipilih ke dalam kolom komik. Pada Gambar 4 dapat dilihat bahwa siswa menggunakan latar belakang ruang tamu dan halaman rumah di frame berikutnya. Pada gambar tersebut juga tulisan terlihat dengan jelas.

\section{E. Membuat balon percakapan}

Pada tahap ini, siswa memilih berbagai bentuk balon komik yang akan digunakan untuk membuat alur cerita dan percakapan dalam komik. Untuk memasukkannya ke dalam komik, cukup pindahkan balon komik yang dipilih ke kolom komik. Setelah itu siswa dapat mengetikkan alur cerita atau kata-kata atau kalimat dalam percakapan. Pada Gambar 5. Terlihat tulisan dalam bentuk "When I at the front of his house, I saw a very big dog". Bagian ini termasuk pada struktur Event atau kejadian. Siswa tersebut menambahkan monologue "The dog is scary". Balom percakapan ini membuat cerita lebih menarik dengan memperlihatkan ekspresi karakter yang sedang takut dikarenakan adanya seekor anjing di depan halamn rumah temannya.
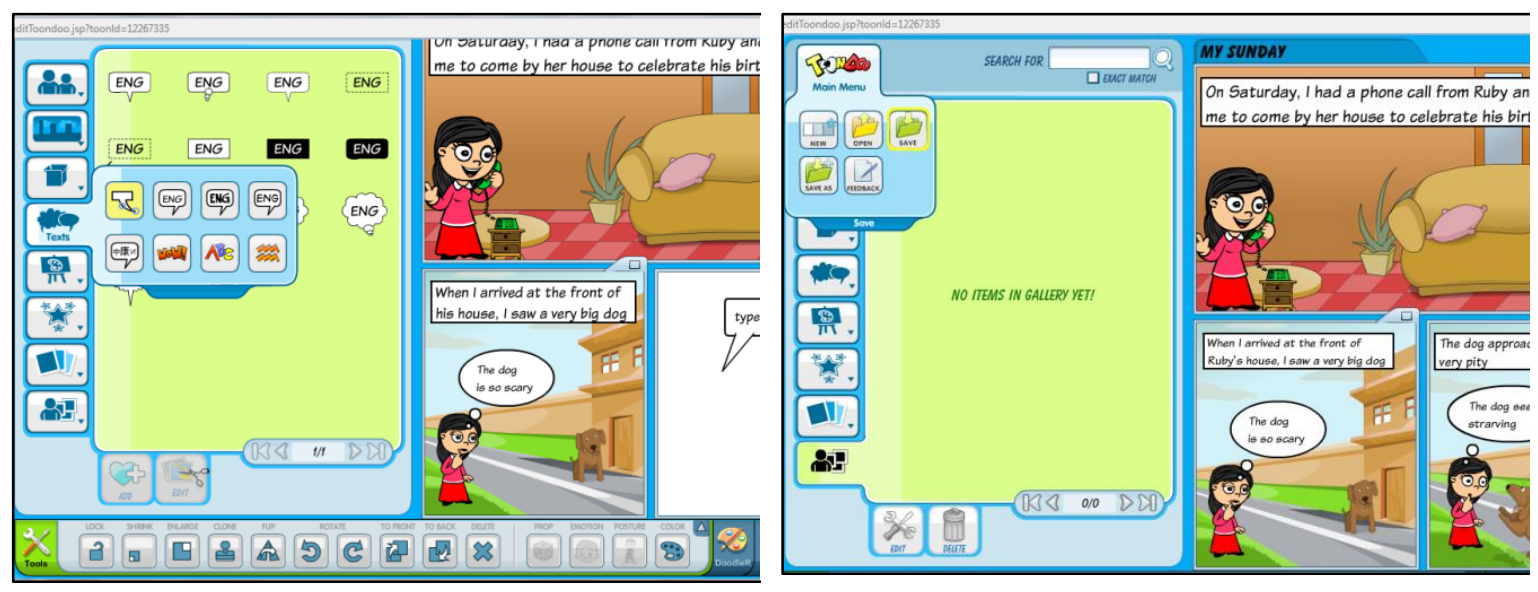

Gambar 5. Membuat Balloon Percakapan Picture dan Opsi Menyimpan 


\section{F. Simpan dan Publikasikan Komik}

Teks Recount berbentuk komik pada Toondo akhirnya dapat disimpan dan dipublikasikan dalam laman www.toondoo.com. Setelah selesai membuat komik, siswa menyimpan karya komik mereka dengan menekan logo Toondoo dan memilih menu simpan. Setelah itu akan muncul kotak di mana pengguna dapat mengisi judul komik, deskripsi, tag, bahasa, dan opsi penerbitan.

\section{Pasca Kegiatan}

Kegiatan ini dimulai dengan melakukan analisis hasil observasi pengukuran keterampilan menulis selama kegiatan proses pengajaran bahasa Inggris dengan penggunaan Toondoo berlangsung. Proses pelaksanaan Toondoo ini selanjutnya disosialisasikan kepada guru pengajar Bahasa Inggris di SMPN 2 Sekampung Udik. Selain itu, hasil angket minat dan sikap juga akan dianalisis untuk mengetahui tingkat minat siswa dalam belajar menulis teks recount menggunakan Toondoo. Kegiatan ini pengajaran Bahasa Inggris dengan menggunakan Toondoo juga direkam pada video yang dipublikasikan diwebsite sekolah maupun channel Youtube.

\section{KESIMPULAN}

Hasil PKM ini menunjukkan bahwa penggunaan pembuat komik pada Toondoo dapat memfasilitasi guru Bahasa Inggris untuk mengajar teks recount untuk kelas 8 tingkat menengah. Penggunaan situs web Toondoo.com dianggap efektif karena fitur-fiturnya ramah pengguna dan melayani tujuan pelajaran. Selain itu, situs web ini menyediakan beragam karakter dan warna-warni yang merangsang siswa untuk berpikir kreatif membuat teks recount berbasis komik. Disarankan bahwa penelitian lebih lanjut mengeksplorasi efek komik digital dalam meningkatkan kemampuan menulis siswa.

\section{ACKNOWLEDGEMENT}

Special credit is given to the Ministry of Research, Technology, and Higher Education Republic of Indonesia that fully sponsored the PKM conducted by the writer.

\section{REFERENCES}

Wahyudin, A.Y. (2015). Teacher's implementation of scientific method to teach english as a foreign language at senior high school level. Unpublished postgraduate thesis. School of Postgraduates Indonesia University of Education

Wahyudin, A.Y. (2012). The effect of outlining strategy in improving students' recount text writing ability at the second year students of SMPN 13 Bandar Lampung. Unpublished undergraduate thesis. Lampung University

Juwitasari, Ratna. (2005). Increasing Student's Descriptive Writing through CTL. Unpublished Undergraduate Thesis. Lampung University.

Sutarsyah, C. (2017). Pembelajaran Bahasa Inggris sebagai muatan lokal pada sekolah dasar di Provinsi Lampung. Aksara, 18(1), pp. 35-43.

Kamus Besar Bahasa Indonesia Edisi ke V. (2016). Badan Pengembangan dan Pembinaan Bahasa, Kementrian Pendidikan dan Kebudayaan Republik Indonesia.

Wright, G. \& Sherman, R. (1994). What is black and white and read all over? The funnies! Reading Improvement, $31(1), 37-48$

McCloud, S. (1993). Understanding Comics: The Invisible Art. New York: Harpercollins.

Hurlock. E. B. (1978). Perkembangan Anak. Jakarta: Penerbit Erlangga.

Martin, J. R., \& Rose, D. (2005). Designing literacy pedagogy: Scaffolding democracy in classroom. In J. Webster, C. Matthiessen, \& R. Hasan (Eds.) Continuing discourse on language (pp.1-26). London: Continuum.

Derewianka, B. (1990). Exploring how texts work. Newtown: PETA.

Megawati, F. \& Anugerahwati, M. (2012). Comic strips: a study on the teaching of writing narrative texts to Indonesian EFL students. Teflin, 23(2), 183-205.

Emilia, E. (2005). A critical genre-based approach to teaching academic writing in a tertiary EFL context in Indonesia. Disertasi PhD. Melbourne University.

Hyland, K. (2007). Genre pedaogy: language, literacy, and L2 writing instruction. Journal of second language writing. pp. 148-164. Retrieved on http://sciencedirect.com/ on March $26^{\text {th }} 2015$. 